\title{
Pengembangan Sistem Informasi Masjid KH. Ahmad Dahlan Berbasis Website
}

\author{
Information Systems development KH. Ahmad Dahlan Mosque used \\ Website
}

\author{
Abid Yanuar Badharudin ${ }^{1}$, Setiawan Ardi Wijaya ${ }^{2}$ \\ ${ }^{1,2}$ Teknik Informatika-Universitas Muhammadiyah Purwokerto \\ 'abidyanuarbadharudin@ump.ac.id \\ ${ }^{2}$ setiawanardiwijaya@gmail.com
}

\begin{abstract}
ABSTRAK
Masjid KH. Ahmad Dahlan merupakan masjid dengan kategori masjid di tempat publik terdaftar pada sub direktorat kemasjidan, Kementrian Agama Republik Indonesia dengan no id.masjid 01.6.14.02.20.00005 (Direktorat Jenderal Bimbingan Masyarakat Islam, n.d.). Masjid beralamat di kampus 1 Universitas Muhammadiyah Purwokerto Jl. KH. Ahmad Dahlan, Kecamatan Kembaran, Kabupaten Banyumas. Diresmikan pada tanggal 8 Mei 1991 oleh Yayasan Amal Bakti Muslim Pancasila yang diketuai oleh bapak HM. Soeharto. Pegembangan sistem informasi masjid ini menyesuaikan kebutuhan yang ada di Masjid KH. Ahmad Dahlan Universitas Muhammadiyah Purwokerto. Data penelitian ini diperoleh dengan wawancara terhadap pengurus tamir masjid, observasi, dan studi dokumentasi penunjang proses kegiatan. Metode pengembangan yang digunakan dalam aplikasi ini menggunakan metode Skuensial Linier. Penelitian ini menghasilkan pengembangan sistem informasi masjid KH. Ahmad Dahlan Universitas Muhammadiyah Purwokerto berbasis website yang diharapkan dapat membantu pihak Tamir masjid dalam hal keterbukaan informasi dan publik dari setiap agenda yang diadakan oleh ta'mir maupun pelaporan keuangan masjid, sehingga dorongan implementasi undang-undang No 14 tahun 2008 tentang keterbukaan informasi publik dapat terlaksana dengan baik.
\end{abstract}

Kata kunci: Sistem Informasi, Web, Masjid

\section{ABSTRACT}

KH Ahmad Dahlan Mosque is a mosque with the category of the mosque in a public place registered with the sub-directorate of the mosque, the Ministry of Religion of the Republic of Indonesia with no id.masjid 01.6.14.02.20.00005 (Direktorat Jenderal Bimbingan Masyarakat Islam, n.d.). The mosque is located on campus 1 University of Muhammadiyah Purwokerto Jl. KH Ahmad Dahlan, Kembaran District, Banyumas Regency. Inaugurated on May 8, 1991, by the Pancasila Muslim Charity Foundation, chaired by Mr. HM. Suharto. The development of the mosque's information system adjusts to the needs of the KH. The Ahmad Dahlan Mosque University of Muhammadiyah Purwokerto. The research data were obtained by interviewing the management of the mosque's Tamir, observation, and study of documentation to support the activity process. The development method used in this application uses the Linear Skuential method. This research resulted in Information Systems development KH. Ahmad Dahlan Mosque used a Website that is expected to help the Ta'mir mosque in terms of public information disclosure of every agenda and financial reporting so that the impetus for the 
implementation of law No. 14 of 2008 concerning public information disclosure can be done well.

Keywords: Information Systems, Web, Mosque.

\section{PENDAHULUAN}

Sistem informasi adalah suatu sistem di dalam organisasi yang mempertemukan kebutuhan pengelolaan transaksi harian, mendukung operasi, bersifat manajerial, dan kegiatan strategi dari suatu organisasi dan menyediakan pihak luar tertentu dengan laporan-laporan yang dibutuhkan (Hutahaean, 2014). Pada hakikatnya mendapatkan informasi adalah hak asasi manusia dan keterbukaan informasi publik merupakan salah satu ciri penting negara demokratis yang menjunjung tinggi kedaulatan rakyat untuk mewujudkan penyelenggaraan negara yang lebih baik (Riyanto, 2012).

Masjid KH. Ahmad Dahlan merupakan masjid dengan kategori masjid di tempat publik terdaftar pada sub direktorat kemasjidan, Kementrian Agama Republik Indonesia dengan no id.masjid 01.6.14.02.20.00005 (Direktorat Jenderal Bimbingan Masyarakat Islam, n.d.). Masjid ini berlokasi di kampus 1 Universitas Muhammadiyah Purwokerto yang beralamat Jl. KH. Ahmad Dahlan, Kecamatan Kembaran, Kabupaten Banyumas Masjid ini diresmikan pada tanggal 8 Mei 1991 oleh Yayasan Amal Bakti Muslim Pancasila yang diketuai oleh bapak HM. Soeharto dan dipugar pada tahun 2012. Berbagai kegiaatan yang bersifat rutin maupun sosial kemasyarakatan diselenggarakan oleh Ta'mir masjid KH. Ahmad Dahlan. Diantara kegiatan tersebut antara lain, kajian setelah magrib, TPQ, Pengajian ahad pagi berkerjasama dengan Ranting Muhammadiyah, maupun kegiatan besar amaliah Romadhon, tasaruf zakat fitri dan Idul Adha. Di sisi lain, tidak semua kegiatan tersebut diketahui oleh masyarakat secara luas, terlebih mengenai pembukuan dan pelaporan kas masjid yang hanya disampaikan pada hari jumat sebelum khotbah jumat berlangsung. Penerapan sistem informasi manajemen masjid berbasis web mampu mempermudah dalam pengolahan manajemen data masjid secara efektif dan efisien (Kristanto, 2018)

Penelitian tentang penerapan sistem informasi untuk publik telah banyak dilakukan, Welim dan Sakti (2016) membuat sistem informasi pengelolaan dana masjid pada Yayasan Al-Muhajirin dapat membantu mengetahui informasi penerimaan dan pengeluaran dana pada KAS, dilengkapi fitur cetak laporan pendapatan dan pengeluaran secara terperinci dan efesien. Sedangkan Fitri et al. (2017) mengembangkan Sistem Informasi Desa yang dapat memberikan inovasi bagi kantor pemerintahan desa untuk dapat meningkatkan kinerja perangkat desa ditinjau dari segi kualitas pelayanan terhadap masyarakat, produktivitas, responsivitas, responsibilitas dan produktifitas di Desa Bamban Selatan Kabupaten Hulu Sungai Selatan Provinsi Kalimantan Selatan.

\section{METODE}

Penelitian ini mengembangkan sistem informasi masjid berdasarkan kebutuhan di Masjid KH. Ahmad Dahlan Universitas Muhammadiyah Purwokerto. Pengumpulan data dilakukan dengan dua cara, melalui observasi dan wawancara terhadap pengurus ta'mir Masjid, serta studi dokumentasi penunjang terkait proses kegiatan yang ada di Masjid KH. Ahmad Dahlan, maupun proses bisnis pelaporan keuangan Kas Masjid. Metode pengembangan yang digunakan dalam aplikasi ini menggunakan metode Skuensial Linier seperti ditunjukkan pada Gambar 1. 


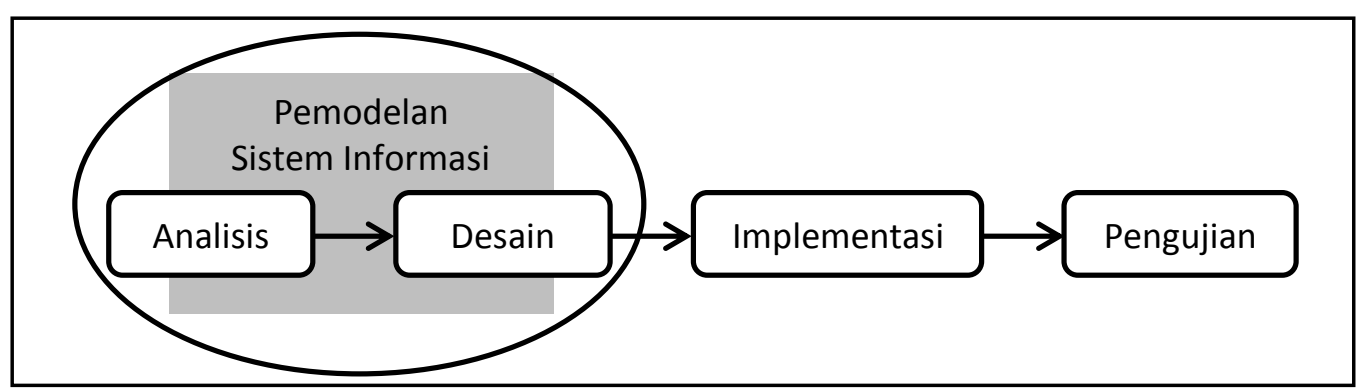

Gambar 1. Metode Skuensial Linier (A S \& Shalahuddin, 2015)

Analisis yang dilakukan dengan mengumpulkan kebutuhan data dan mempelajari data, dari hasil observasi dan wawancara kemudian dianalisa dari permasalahan tersebut nantinya akan digunakan sebagai acuan untuk desain sistem. Kemudian menganalisis kebutuhan-kebutuhan sistem yang akan digunakan untuk perancangan serta pengembangan sistem agar dapat bekerja sesuai yang diharapkan pengguna.

Dalam tahap desain yang dilakukan adalah menentukan arsitektur sistem secara keseluruhan yang diimplementasikan dari hasil proses analisis data-data yang dibutuhkan dalam alur kerja pembuatan aplikasi.

a. Use Case Diagram merupakan teknik untuk merekam persyaratan fungsional sebuah sistem. Use case mendeskripsikan interaksi tipikal antara para pengguna sistem dengan sistem itu sendiri, dengan memberi sebuah narasi tentang bagaimana sistem tersebut digunakan (The Pearson Education, 2005). Pada sistem informasi Masjd KH. Ahmad Dahlan, Use Case Diagram dimaksudkan untuk mengetahui fungsi apa saja yang ada dalam sebuah sistem dan siapa saja yang berhak menggunakan fungsi-fungsi tersebut.

b. Database adalah salah satu komponen utama yang akan diolah dan dijadikan informasi. Pada sistem informasi masjid ini menggunakan database MySQL dengan disertai rancangan relasi antar tabel di dalamnya.

c. Desain antarmuka merupakan mekanisme komunikasi pengguna (user) untuk membantu mengarahkan alur penelusuran masalah, hingga ditemukan sebuah solusi dan kemudahan dalam pemakaian, interaktif dan komunikatif.

Pada tahapan Implementasi, bahasa yang digunakan adalah php, adapun tools yang digunakan adalah Sublime Text 3 dan XAMPP. Kode pemrograman ini berfungsi untuk mengolah data-data yang ada. Dengan kode program ini menjadikan antarmuka dan database dapat saling terhubung sehingga data dapat ditampilkan pada tampilan antarmuka dan dapat disimpan dalam database.

Pengujian menggunakan Black-Box Testing (pengujian kotak hitam). Menurut Rosa A S dan Shalahuddin (2015) Black-Box Testing yaitu menguji perangkat lunak dari segi spesifikasi fungsional tanpa menguji desain dan kode program. Pengujian dimaksudkan untuk mengetahui apakah fungsi-fungsi, masukan, dan keluaran dari perangkat lunak sesuai dengan spesifikasi yang dibutuhkan. Apabila terdapat kesalahan maka dapat segera dilakukan perbaikan hingga sistem siap untuk diserahkan kepada admin pengguna aplikasi.

\section{HASIL DAN PEMBAHASAN}

Sistem informasi masjid KH. Ahmad Dahlan berbasis website memuat informasi mengenai data kajian, data artikel, data keuangan, data pengumuman certak laporan masjid KH.Ahmad Dahan serta informasi laporan keuangan maupun laporan kegiatan 
yang dilakukan oleh Ta'mir masjid KH.Ahmad Dahlan. Kebutuhan pemakai meliputi orang-orang yang terlibat dalam sistem yang telah dibangun, yaitu admin dan user. Berikut Use case diagram pada Gambar 2 menjelaskan dalam sistem ini, admin bertugas untuk mengelola data artikel, mengelola data kajian ,mengelola data keuangan, cetak laporan keuangan, mengelola data pengumuman, dan mengelola data tentang

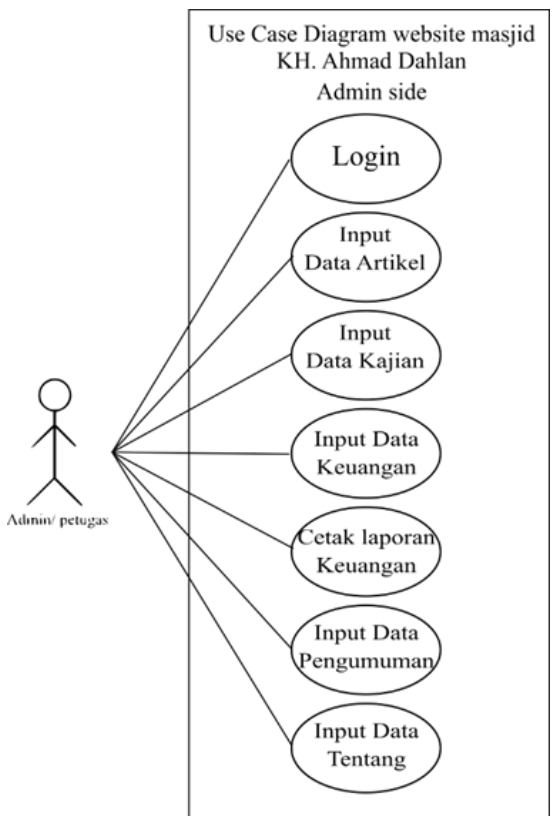

\section{Gambar 2. Use Case Diagram website masjid KH.Ahmad Dahlan Admin side}

Adapun pada user dapat melakukan beberapa hal antara lain, melihat data artikel, melihat data kajian ,melihat data keuangan, melihat data pengumuman, dan melihat data tentang. Berikut Use case Diagram User side pada Gambar 3.

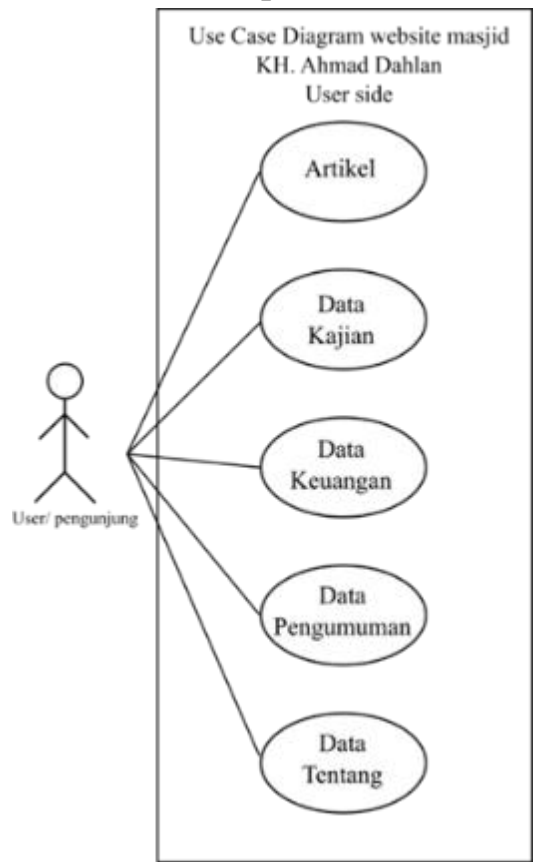

Gambar 3. Use Case Diagram website masjid KH.Ahmad Dahlan User side 
Dalam perancangan sistem terdapat permodelan data dan perancangan interface. Pada permodelan data digunakan database $M y S q l$. Gambar 4 Berikut ini adalah tabel yang digunakan dalam sistem informasi masjid serta relasi antara tabel kajian (tb_kajian) dan lookup keterangan (1_ket).

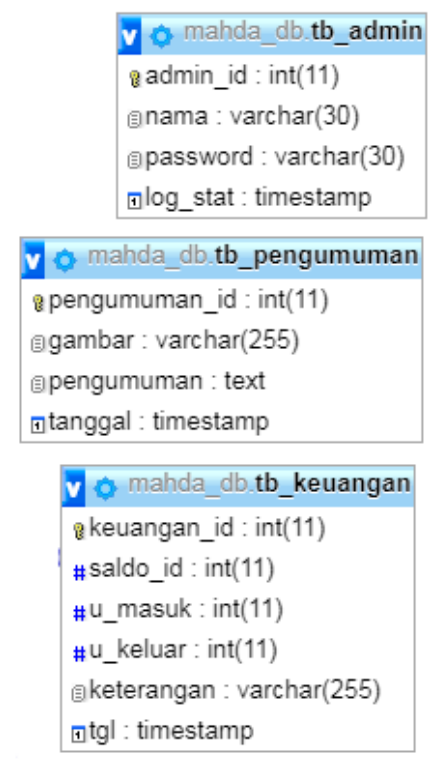

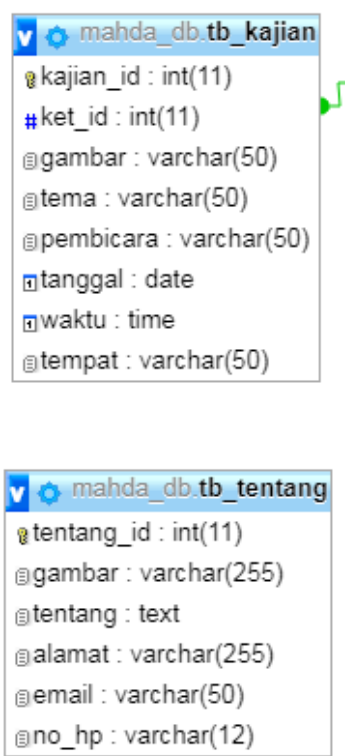

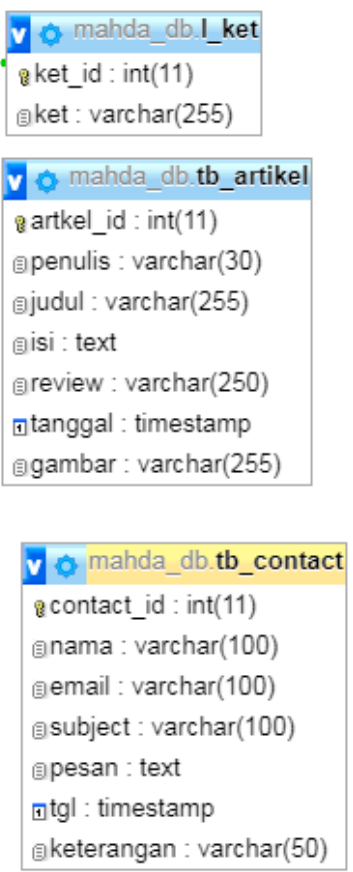

\section{Gambar 4. Tabel pada database $M y S q l$ dengan relasi antar tabel}

Pada perancangan user interface atau rancangan antar muka back end disesuaikan dengan kebutuhan sistem informasi masjid, antara lain berisi: layout login, layout halaman, layout menu, daftar menu, hingga menu cetak laporan keuangan. Berikut gambar 5 desain login back end.

\section{username}

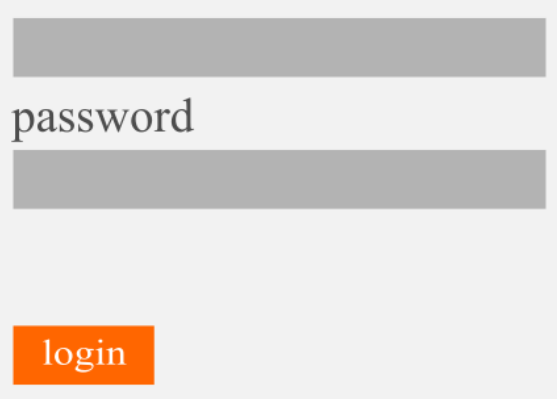

\section{Gambar 5. Desain Login back end}

Desain tampilan pada user merupakan halaman untuk menampilkan data-data yang telah diinputkan oleh admin, adapun user tidak dapat mengakses maupun mengubahnya. Berikut gambar 6 terdapat beberapa bagian yaitu : menu bar, cover, konten dan widget. 


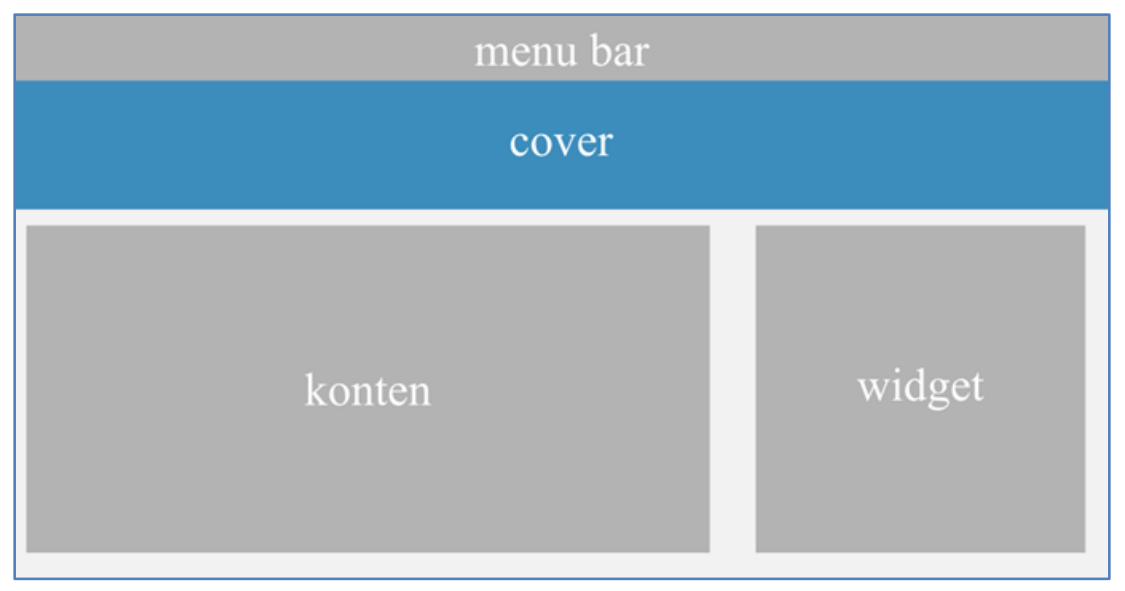

\section{Gambar 6. Desain tampilan antar muka user}

Dalam tahap penulisan kode program data-data yang telah dikumpulkan dan dirancang kemudian diubah menjadi aplikasi menggunakan bahasa pemrograman php. Tahap pengkodean dilakukan setelah peancangan database dan perancangan antar muka selesai dilakukan. Form login admin di bawah ini merupakan tampilan pertama sebelum admin masuk ke menu utama side admin ditunjukan pada gambar 7. Pada halaman login admin, admin diminta untuk mengisikan username dan password yang telah didaftarkan. Apabila username dan password yang diinputkan salah maka sistem akan memberi pesan 'gagal masuk' dan apabila tidak menginputkan username dan password maka sistem juga akan memberi pesan 'gagal masuk'.

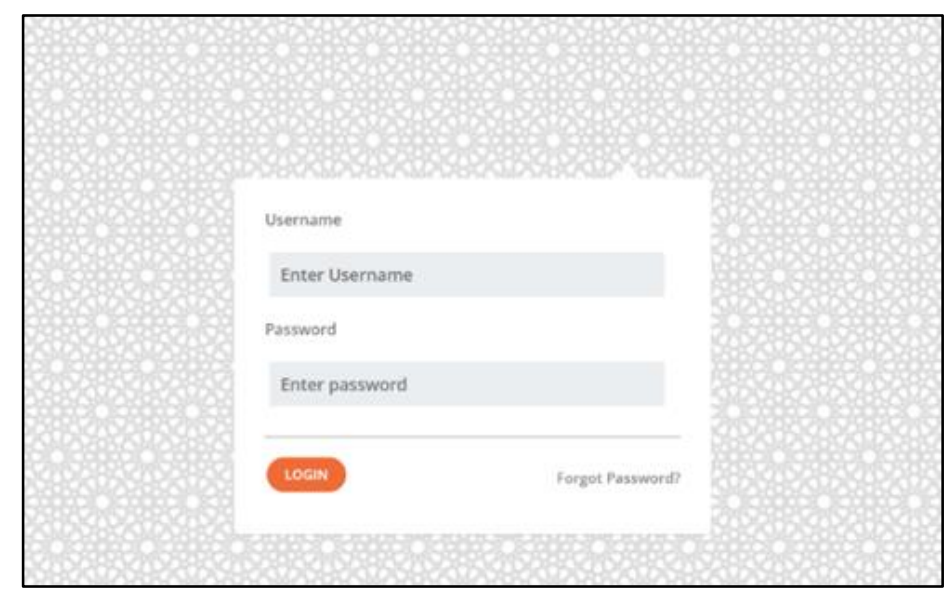

Gambar 7. Tampilan login admin

Form menu utama admin merupakan tampilan utama yang hanya dapat dilihat oleh admin setelah admin berhasil melakukan login. Pada tampilan menu utama tersebut terdapat data seperti jumlah keuangan, jumlah artikel, jumlah kajian dan jumlah pesan yang masuk seperti pada gambar 8 . 


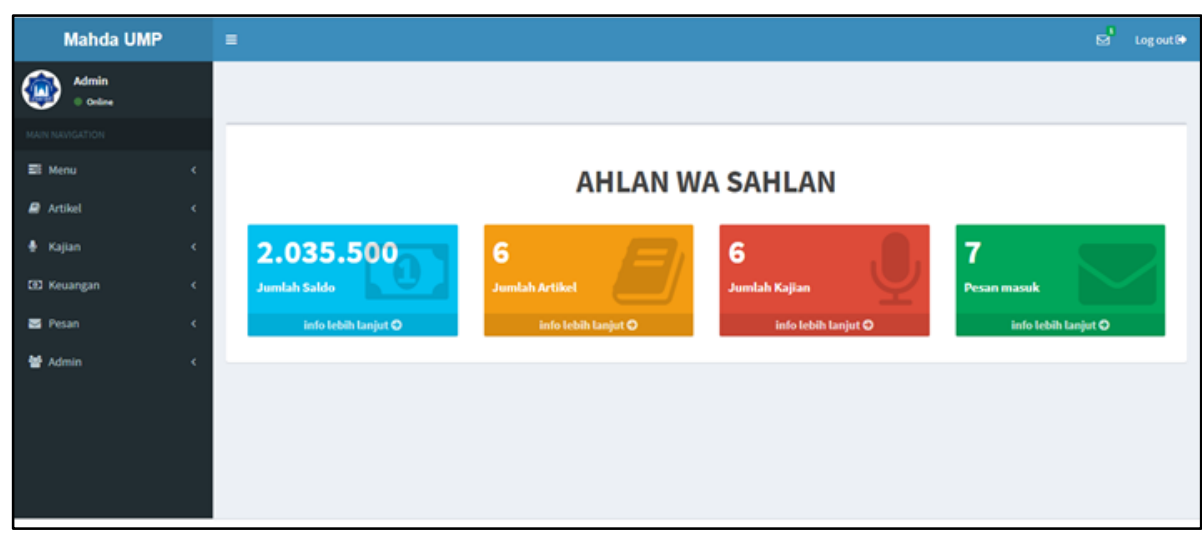

Gambar 8. Tampilan menu utama

Pada menu keuangan, admin dapat melakukan updating data, melakukan laporan keuangan dan mencetak laporan berdasarkan kategori yang dipilih, seperti pada gambar 9 . Adapun pada gambar 10 merupakan tampilan hasil cetak laporan berdasarkan filter yang dipilih.

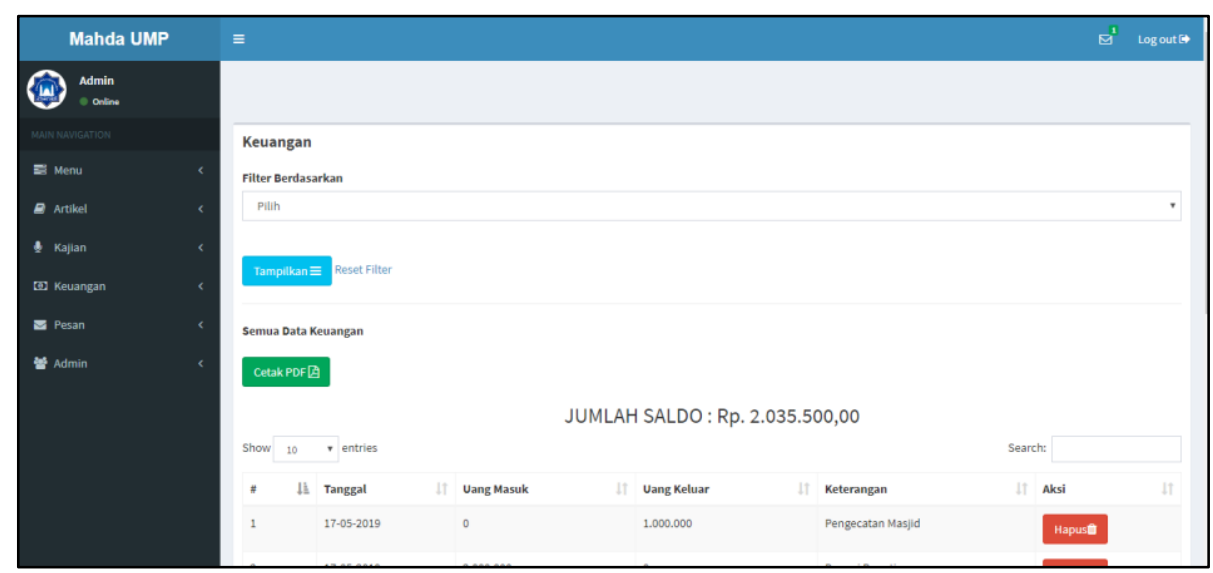

Gambar 9. Tampilan pada menu keuangan

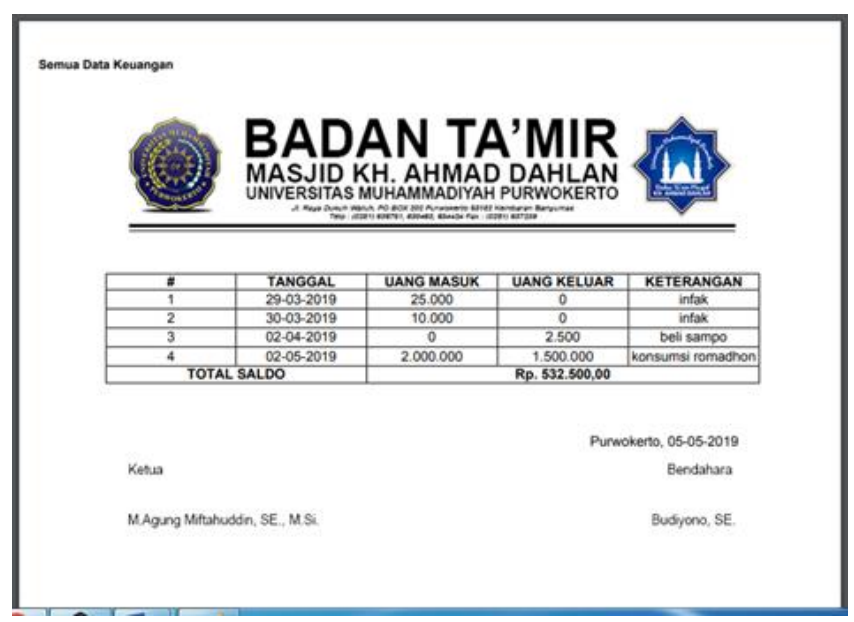

Gambar 10. Tampilan cetak laporan keuangan 
Pada menu artikel, admin dapat menginputkan, merubah maupun menghapus artikel. Artikel yang diinputkan dapat berasal dari rangkuman kajian yang ada dimasjid KH. Ahmad Dahlan maupun dari tulisan ustadz yang mengisi kajian.

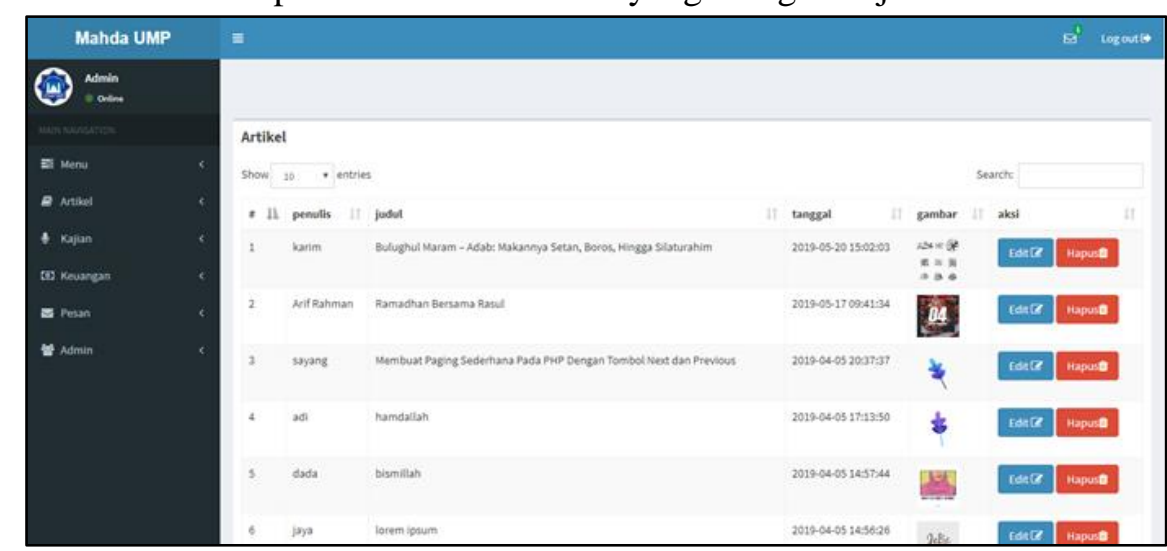

Gambar 11. Tampilan pada menu artikel

Untuk form kajian admin dapat menginputkan dan menghapus data kajian yang ada di Masjid KH. Ahmad Dahlan berdasarkan kategori kajian seperti : kajian ba'da magrib, kajian ba'da asar, kajian kemuslimahan, kajian tematik dan kajian ahad pagi.

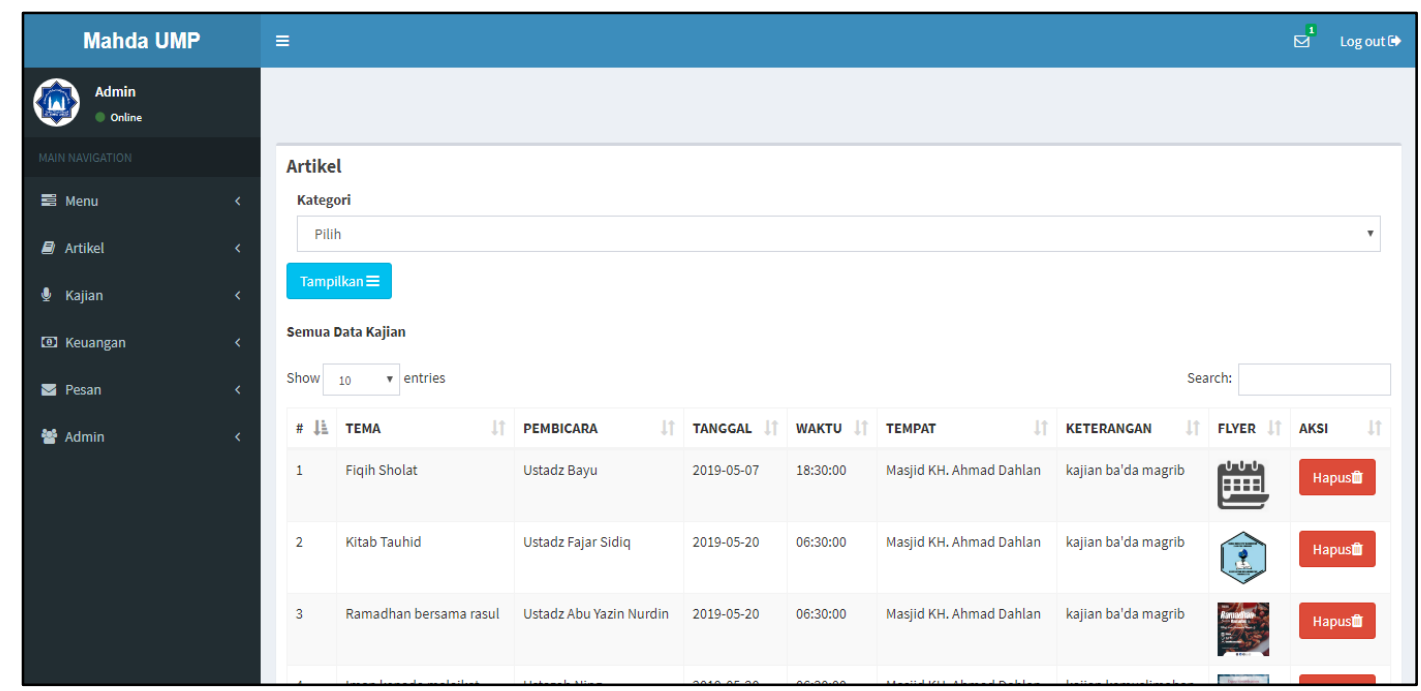

Gambar 12. Tampilan pada menu kajian

Pada form contact us atau pesan, admin dapat melihat pesan masuk yang dikirimkan oleh user. Admin membalas pesan melalui alamat email yang dicantumkan oleh user saat mengirim pesan berikut tampilannya pada Gambar 13. 


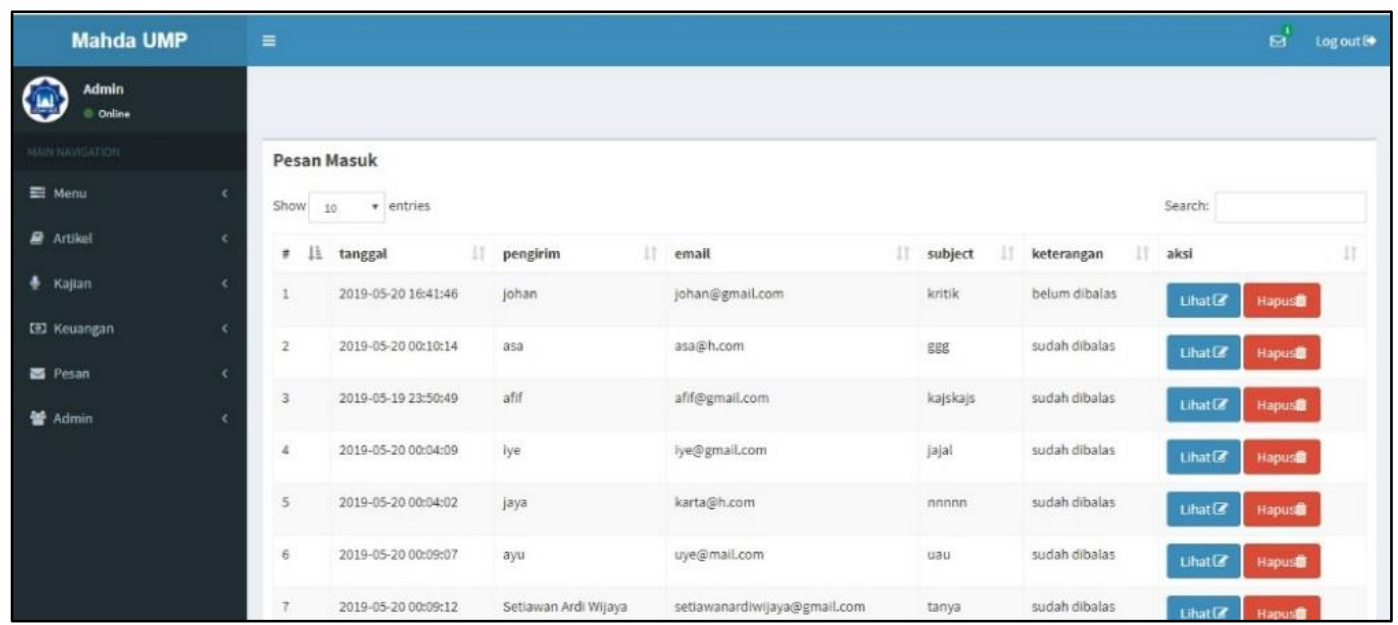

Gambar 13. Tampilan pesan/ contact us

Pada form user side terdapat beberapa menu yang dapat dilihat oleh user seperti : menu home berisi rangkuman dari semua menu yang ada, menu tentang yang berisi profil singkat masjid KH. Ahmad Dahlan, menu kajian yang berisi informasi seputar kajian yang ada di masjid, menu artikel yang berisi artikel-artikel yang diambil dari ringkasan kajian, menu info saldo yang berisi informasi tentang saldo masjid per sepuluh transaksi terakhir, dan contact us atau pesan yang dapat digunakan user untuk menulisakan kritik dan saran. Berikut tampilan halamannya seperti pada gambar 14.

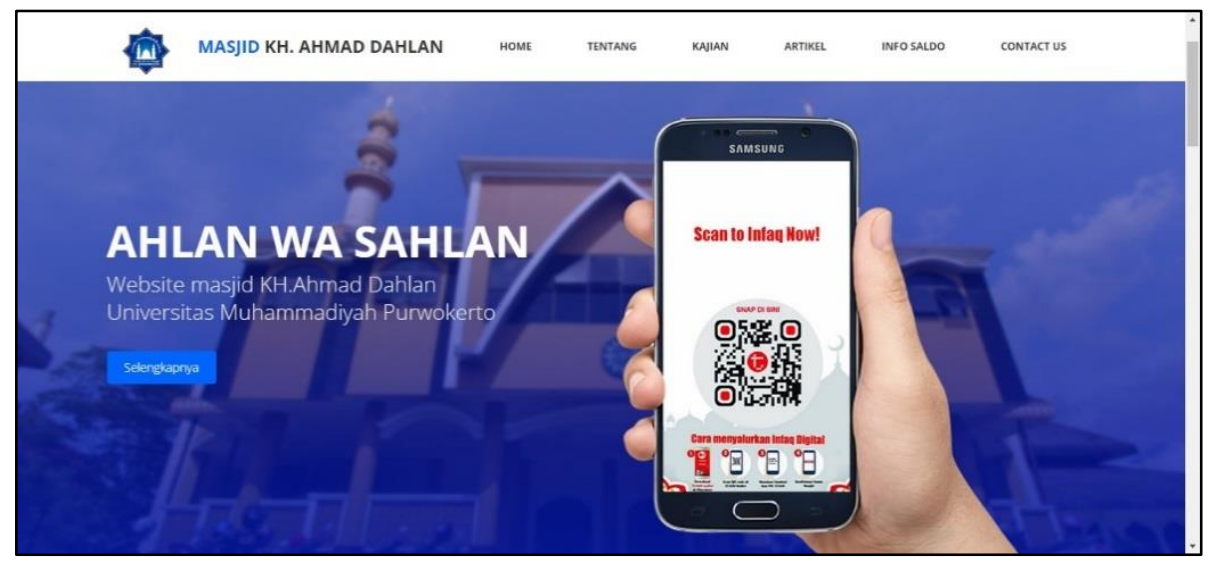

Gambar 14.Tampilan halaman user side

Tahap pengujian dilakukan untuk melihat dan mengetahui apakah aplikasi yang telah dibangun dapat berjalan dengan baik serta sesuai dengan kebutuhan. Pengujian dilakukan terhadap setiap fungsi yang ada dalam aplikasi, serta memastikan berjalannya fungsi tersebut dengan baik. Apabila terjadi kerusakan, maka segera diperbaiki.

\section{KESIMPULAN}

Penelitian ini telah menghasilkan sebuah sistem informasi masjid KH. Ahmad Dahlan Universitas Muhammadiyah Purwokerto berbasis website yang diharapkan dapat membantu pihak Ta'mir masjid dalam hal keterbukaan informasi dan publikasi dari setiap agenda yang diadakan oleh ta'mir maupun pelaporan keuangan masjid, sehingga 
dorongan implementasi undang-undang No 14 tahun 2008 tentang keterbukaan informasi publik dapat terlaksana dengan baik.

\section{DAFTAR PUSTAKA}

A S, R., \& Shalahuddin, M. (2015). Rekayasa Perangkat Lunak ( Terstruktur dan Berorientasi Objek). Informatika.

Direktorat Jenderal Bimbingan Masyarakat Islam. (n.d.). Sistem Informasi Masjid Kementrian Agama Republik Indonesia. Retrieved November 2, 2019, from https://simas.kemenag.go.id/profil/masjid/262176

Fitri, R., Asyikin, A. N., \& Nugroho, A. S. B. (2017). Pengembangan Sistem Informasi Desa Untuk Menuju Tata Kelola Desa Yang Baik (Good Governance) Berbasis Tik. POSITIF: Jurnal Sistem Dan Teknologi Informasi, 3(2), 99. https://doi.org/10.31961/positif.v3i2.429

Hutahaean, J. (2014). Konsep Sistem Informasi. Deepublish.

Kristanto, D. (2018). Sistem Informasi Pengelolaan Masjid Ibaadurrahman Berbasis Web. Univeristas Muhammadiyah Surakarta.

Riyanto, A. (2012). Pemahaman Undang-Undang Nomor 14 Tahun 2008 Tentang Keterbukaan Informasi Publik. In Jurnal Hukum \& Pembangunan (Vol. 42, Issue 4, p. 381). https://doi.org/10.21143/jhp.vol42.no4.270

The Pearson Education, I. (2005). UML Distilled ED.3, Panduan Singkat Bahasa Permodelan (1st ed.). Andi.

Welim, Y. Y., \& Sakti, A. R. (2016). RANCANG BANGUN SISTEM INFORMASI ADMINISTRASI PENGELOLAAN DANA MASJID PADA YAYASAN ALMUHAJIRIIN, TANGERANG. Simetris : Jurnal Teknik Mesin, Elektro Dan Ilmu Komputer. https://doi.org/10.24176/simet.v7i1.485 